\section{Cellular Physiology and Biochemistry}

\title{
Effect of Proinflammatory Cytokines, Tumor Necrosis Factor- $\alpha$ and Interferon- $\gamma$ on Epithelial Barrier Function and Matrix Metalloproteinase-9 in Madin Darby Canine Kidney Cells
}

\author{
Amanda K. Leone ${ }^{1}$, Jennifer A. Chun², Christopher L. Koehler ${ }^{2}$, \\ Jonathan Caranto ${ }^{2}$ and Jonathan M. King ${ }^{2}$
}

\begin{abstract}
${ }^{1}$ Southwestern Graduate School of Biomedical Sciences, UT Southwestern Medical Center, 5323 Harry Hines Blvd., Dallas, ${ }^{2}$ Trinity University, Biology Department, One Trinity Place, San Antonio; AKL and JAC contributed equally to this study
\end{abstract}

\section{Key Words}

Matrix metalloproteinase $\cdot$ Tumor necrosis factor- $\alpha \bullet$ MDCK cells - Epithelial barrier - MMP-9 gene expression • Zymography

\begin{abstract}
Background: Elevated matrix metalloproteinase-9 production during inflammation may be deleterious to epithelial barrier function. Therefore we examined the effect of proinflammatory cytokines on the expression and regulation of matrix metalloproteinase9 in a model renal epithelial cell system. Tight junctions limit diffusion between compartments and permit directional transport of solutes. Impairment of these junctional complexes by proteolysis may contribute to renal failure through loss of barrier function. Methods: The renal epithelial cell model, MDCK cells were employed to examine metalloproteinase activity
\end{abstract}

and mRNA expression. Epithelial barrier function was determined using paracellular flux studies. Results: We found that matrix metalloproteinase-9 expression (MMP-9) and activity is markedly elevated in response to tumor necrosis factor- $\alpha$ exposure through a mitogen-activated protein kinase dependent pathway. The MMP-9 is predominately secreted into the apical compartment and elevated MMP-9 expression correlates with impaired cell barrier function that was restored using a specific inhibitor of MMP activity. Addition of recombinant MMP-9 to the apical compartment of MDCK cultures significantly elevated paracellular flux rate. Conclusions: We provide direct evidence for a MMP-9-mediated mechanism that produces junctional disruption. Collectively, these findings support the hypothesis that impaired epithelial barrier function due to activation of tissue/matrix degrading mechanisms occurs in response to specific inflammatory cues.

\section{KARGER}

Fax +4161306 1234

E-Mail karger@karger.ch

www.karger.com
(C) 2007 S. Karger AG, Basel

1015-8987/07/0194-0099\$23.50/0

Accessible online at:

www.karger.com/journals/net
Jonathan M. King, Ph.D.

Trinity University, 1 Trinity Place, San Antonio, TX 78212 (USA)

Tel. +1210 999-7232, Fax +1210 999-7229

E-Mail jking@trinity.edu, or E-Mail ckoehler@trinity.edu 


\section{Introduction}

Epithelia serve a variety of essential functions through the compartmentalization of tissues and formation of selectively permeable surfaces required for regulated vectorial transport of solutes. The tight junctions that connect adjacent epithelial cells play a fundamental role in these processes [1-3]. Disruption of epithelial barrier function results in a loss of regulated transport and increased flux of fluid and solutes across the epithelial monolayer. In a recent review by Lee et. al. [4], the authors highlight the connection between tight junction physiology and several renal disorders including renal fibrosis and acute renal failure. Our group is interested in physiological consequences of inflammatory episodes that may result in compromised renal tubular cell function due to loss of junctional integrity.

Matrix metalloproteinases (MMP) are a family of enzymes involved in physiological and pathophysiological processes; classically, these enzymes are involved in tissue remodelling. There are over 25 identified members of MMPs which have a variety of substrates, including extracellular matrix components, cell surface receptors, adhesion proteins and matrix bound growth regulators $[5$, 6]. Tissue inhibitor of metalloproteinases (TIMPs) were isolated and characterized from connective tissue [7-9] and serve as endogenous active site inhibitors of MMPs. Aberrant MMP activity has been linked to major renal disorders including diabetic nephropathy $[10,11]$, membranous nephropathy [12], polycystic kidney disease [13] and chronic renal failure [14]. In addition to MMPs, there are a variety of other proteases that have been identified in the kidney, such as a disintegrin and metalloproteinase with thrombospondin motifs (ADAMTS), which may be involved in acute inflammatory response $[15,16]$.

It has been suggested by previous studies that MMP9 has a role in multiple inflammation mediated pathophysiologies. For example, in a study of induced distal colitis, researchers demonstrated elevated levels of MMP9 and a decrease in barrier function [17]. In addition to its role in renal disease, MMP-9 has been suggested as an effector in blood brain barrier damage following ischemia [18]. The increased MMP-9 activity in these conditions has been linked to mitogen-activated protein kinase (MAPK) activity. In vivo inhibition of extracellular signal-regulated kinase kinase (MEK) in wildtype mice protected brain barrier function, reduced ZO-1 degradation and decreased MMP-9 activity [19]. These studies provide support that MAP kinase activity elevates MMP activity which may in turn increase tight junction permeability. Evidence suggests that MMPs have a role in controlling paracellular permeability; MMPs likely exert this control via cleavage of cellular junction proteins such as occludin and cadherin [20].

MMP activation is a complex and multifaceted process with multiple levels of regulation including; transcription, zymogen activation, MMP: TIMP ratio and secretion rates of preformed granules [21-23]. The canine MMP-9 gene promoter was recently demonstrated to be regulated by a variety of growth factors and inflammatory cytokines [24]. The MMP-9 gene promoter contains a nuclear factor- $\kappa \mathrm{B}(\mathrm{NF}-\mathrm{\kappa B})$ recognition element which is unique for MMPs. The NF- $\kappa$ B site in the MMP-9 promoter is not shared with its primary inhibitor TIMP-1, thus allowing for a selective upregulation of MMP-9 by TNF $\alpha$, which is NF- $\kappa \mathrm{B}$ mediated, without a corresponding increase in TIMP-1 production allowing a net activation of MMP-9 [5, 22]. This response is in direct contrast to inflammatory agents such as phorbol esters which act through an AP-1 site which activates both TIMP-1 and MMP-9 thus leading to a corresponding increase in both TIMP-1 and MMP-9 transcription with little net increase in MMP-9 activity [21]. The AP-1 sites are associated with regulation by the MAPK pathway which functions as an upstream trigger. The extracellular signal regulated kinase (ERK) pathway has been shown to have significant positive regulatory effects on the regulation of MMP-9 [19].

We have previously found that the combination of $\mathrm{TNF} \alpha / \mathrm{IFN} \gamma$ induces junctional reorganization in MDCK cells mediated by ERK $1 / 2$ activation [25]. We hypothesized that activation of MMPs following exposure of MDCK cells to proinflammatory cytokines may contribute to a compromised epithelial barrier function. We tested this using MDCK cells subjected to a proinflammatory regiment consisting of $\mathrm{TNF} \alpha$ and/or IFN $\gamma$ to determine a possible role for MMP in the regulation of epithelial permeability.

\section{Materials and Methods}

\section{Materials}

Dulbecco's Minimum Essential Medium Eagle (Mediatech, Herndon, VA), L-glutamine, sodium pyruvate, non-essential amino acids, fetal bovine serum (FBS), penicillin, streptomycin, trypsin/EDTA solution, Corning Costar Tissue Culture flasks six well plates and Transwell Systems were purchased from Fisher Scientific. Inflammatory cytokines human recombinant 
TNF $\alpha$ was purchased from Becton-Dickinson (San Jose, CA), human recombinant IFN $\gamma$ and recombinant mouse MMP-9 were purchased from R\&D Systems (Minneapolis, MN). MAP kinase inhibitors U0126, SB202190 and SB600126 inhibitors were purchased from EMD Biosciences (San Diego, CA). GM6001 and the anti-MMP9 antibody were obtained from Chemicon (Temecula, CA). TRIZOL ${ }^{\mathrm{TM}}$ Reagent and PCR primers were obtained (Invitrogen, Carlsbad, CA). Reverse Transcriptase (RT) master mix, RNase inhibitor and endogenous control, Primer/Probe sets were from Applied Biosystems (Foster City, CA). AccessQuick RT-PCR System was purchased from Promega (Madison, WI). Glycogen and 18S primer:competimers were obtained from Ambion (Austin, TX). Horseradish Peroxidase conjugated anti-rabbit IgG antibody was purchased from Jackson ImmunoResearch Laboratories (West Grove, PA). Sodium fluorescein from Sigma Chemical (St. Louis, MO). All other reagents were of the highest quality available.

\section{Cell Culture}

MDCK Type (CCL-34) cells of the low resistance variety $\left(\sim 120 \Omega * \mathrm{~cm}^{2}\right)$ were obtained from American Type Culture Collections (Manassas, VA). MDCK cells were grown in Dulbecco's Minimum Essential Medium Eagle supplemented with L-glutamine (2 $\mathrm{mM})$, sodium pyruvate $(1 \mathrm{mM})$, nonessential amino acids $(0.1 \mathrm{mM}), 5 \% \mathrm{FBS}$, penicillin $(200 \mathrm{U} / \mathrm{mL})$, streptomycin $(200 \mu \mathrm{g} / \mathrm{mL})$ in a humidified incubator at $37^{\circ} \mathrm{C}$ and $5 \% \mathrm{CO}_{2}$. MDCK cells were passaged using a trypsin $(0.25 \%)$, EDTA $(0.03 \%)$ solution and culture dishes were reseeded following a 1:4 dilution. Laboratory grade water (Millipore) was used for all solutions and the water is routinely tested for the presence of endotoxin using the Limulus Amebocyte Lysate Assay (Sigma, St. Louis, MO).

\section{Protein Isolation}

Cellular proteins were harvested from MDCK cells at indicated times, conditioned media was collected and stored at $-20^{\circ} \mathrm{C}$, the cells were then washed twice with ice-cold PBS. MDCK cells were lysed in buffer containing 1\% Triton X-100, $1 \%$ sodium deoxycholate, $0.1 \%$ SDS, 2 mM EDTA, $0.15 \mathrm{M} \mathrm{NaCl}$, $0.01 \mathrm{M} \mathrm{NaPO}_{4}$, and mini-Complete protease inhibitor (Roche Applied Science). The DNA was sheared using a 27-gauge needle, supernatant was then transferred to a clean $1.5 \mathrm{~mL}$ microcentrifuge tube and centrifuged at $10,000 \times \mathrm{g}$ for 5 minutes at $4{ }^{\circ} \mathrm{C}$. The supernatant was stored at $-20^{\circ} \mathrm{C}$ and the protein was quantified using the BCA method (Pierce, Rockford, IL).

\section{Fluorescent MMP Assay}

Conditioned media was diluted in MMP assay buffer containing (50 mM Tris- $\mathrm{HCl}, 10 \mathrm{mM} \mathrm{CaCl}_{2}, 150 \mathrm{mM} \mathrm{NaCl}, 0.05 \%$ Brij 35 at $\mathrm{pH} 7.5$ ) with $p$-aminophenylmercuric acetate (APMA, $1 \mathrm{mM}$ ) for two hours at $37^{\circ} \mathrm{C}$ to activate MMP. Activated conditioned media was placed in a quartz cuvette and the reaction was initiated by the addition of $10 \mu \mathrm{M}$ (7Methoxycoumarin-4-yl)acetyl-Pro-Leu-Gly-Leu-N-3(2, 4Dinitrophenyl)-L-2, 3-diaminopropionyl-Ala-Arg- $\mathrm{NH}_{2}$ ) [26]. The fluorescence intensity (ex. $320 \mathrm{~nm}$ and em. $405 \mathrm{~nm}$ ) of the reaction was measured every two minutes for two hours at $37^{\circ} \mathrm{C}$ using a
QM-4 spectrofluorometer (Photon Technology International, NJ) or a Synergy HT multiplate reader (BioTek Instruments, VT).

\section{Gelatin Zymography}

Gelatin zymography was used to visualize MMP activity from MDCK cells. Polyacrylamide gels (10\%) were supplemented with reagent grade gelatin $(2 \mathrm{mg} / \mathrm{mL})$. Either cell lysates or conditioned media was collected and protein concentration was determined using the BCA method. Protein samples $(20 \mu \mathrm{g})$ were placed in non-reducing buffer $(0.5 \mathrm{M}$ Tris$\mathrm{HCl} \mathrm{pH} 6.8,20 \%$ glycerol, $2 \% \mathrm{SDS}$, and $0.5 \% \mathrm{w} / \mathrm{v}$ bromophenol blue), loaded and electrophoresed at $70 \mathrm{~V}$ for 2.5 hours. Gels were washed in Zymobuffer (50 mL) containing $200 \mathrm{mM} \mathrm{NaCl}$, $50 \mathrm{mM}$ Tris- $\mathrm{HCl}, 5 \mathrm{mM} \mathrm{CaCl}_{2}, 0.07 \% \mathrm{NaN}_{3}, 1 \mu \mathrm{M} \mathrm{ZnCl}_{2}$ and $2.5 \%$ Triton $\mathrm{X}-100$. The gels were then allowed to incubate in Zymobuffer with 1\% Triton X-100 for up to 48 hours. After incubation, the gel was stained with $0.5 \%$ Coomassie blue and destained accordingly until bands of MMP activity were visible against the dark blue background.

\section{Western Blot Analysis}

Cellular protein $(20 \mu \mathrm{g})$ in sample buffer was heating at $95^{\circ} \mathrm{C}$ for 5 minutes and then loaded onto SDS-polyacrylamide gels $(10 \%)$. The proteins samples were electrophoresed at $70 \mathrm{~V}$; the protein from the gel was then transferred to PVDF membrane using a semi-dry transfer apparatus. The PDVF membranes were rinsed twice with TBS-T and then blocked using 5\% Nonfat milk. The rabbit MMP-9 antibody was diluted 1:500 and allowed to shake overnight at $4{ }^{\circ} \mathrm{C}$. The membranes were again washed twice with TBS-T. The anti-rabbit HRP secondary antibody was diluted 1:10,000 in TBS-T with 5\% non-fat milk solution. The membranes were developed using the Pierce SuperSignal West Pico development kit. Images were acquired using a Bio-Rad VersaDoc 3000.

\section{RNA Isolation}

MDCK cells were washed twice with sterile PBS following cell treatments and then allowed to shake in $500 \mathrm{uL}$ TRIZOL $^{\mathrm{TM}}$ for approximately 15 minutes at room temperature. Glycogen $(7.5 \mu \mathrm{L})$ was added to each well and the cell lysates were transferred to the microcentrifuge tubes. Chloroform $(100 \mu \mathrm{L})$ was added to each tube, shaken vigorously for 15 seconds and centrifuged for 10 minutes at $4^{\circ} \mathrm{C}$ at $12,000 \mathrm{xg}$. The aqueous layer was transferred to a clean microcentrifuge tube and isopropanol $(250 \mu \mathrm{L})$ was added to each tube, tubes were vortexed and incubated on ice for 10 minutes. The RNA was again centrifuged for 10 minutes at $4^{\circ} \mathrm{C}$ at $12,000 \mathrm{xg}$. The supernatant was discarded and $1 \mathrm{~mL}$ of cold $75 \%$ ethanol was added to each tube. The RNA was then stored at $-20^{\circ} \mathrm{C}$ in pellet form in ethanol until needed for the RT-PCR reactions. In order to prepare RNA for RT-PCR reactions the ethanol was removed by centrifugation, and air dried at room temperature for 10 minutes. The RNA pellets were resuspended in DEPCtreated water $(50 \mu \mathrm{L})$ on ice. RNA was quantified using a Beckman DU-200 spectrophotometer. 
Fig. 1. Effect of Substrate Inhibitor GM6001 on MDCK Cell Barrier Function. MDCK cells grown to confluency on Transwell inserts were treated for twenty-four hours prior to onset of flux assay. The basolateral compartment was sampled one hour following the addition of fluorescein, a $0.3 \mathrm{kDa}$ tracer to the apical compartment. The fluorescence was measured using a fluorescence spectrophotometer (ex. $490 \mathrm{~nm}$, em. 530 $\mathrm{nm})$. There is a significant elevation in permeability in the TNF $\alpha(10 \mathrm{ng} / \mathrm{mL})$ and IFN $\gamma(20 \mathrm{ng} / \mathrm{mL})$, GM6001 partially restored the flux levels toward control values. The mean fluorescence intensity is reported, error bars represent the SE, significance was determined by ANOVA with Tukey post-hoc comparison, $* * \mathrm{P}<0.05(\mathrm{n}=4)$.

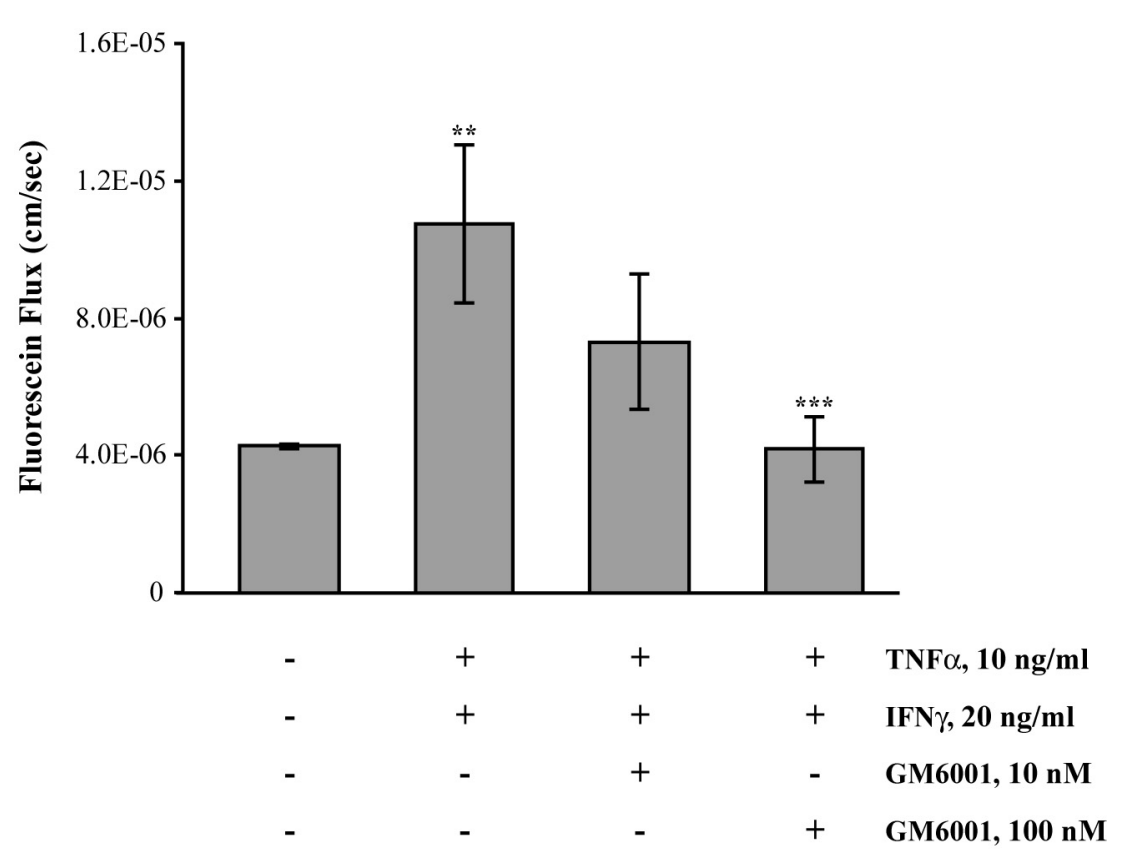

\section{mRNA Expression}

Relative quantitative (RQ) RT-PCR was performed according to a protocol by Ambion (Austin,TX). Briefly, total purified RNA is treated with DNase I to remove any contamination by DNA prior to RT-PCR reactions. Control RT reactions are done in which the RT enzyme or RNA is omitted and the number of PCR cycles are determined to be within the linear range of amplification. Primers to Canis familiaris matrix metalloproteinase-9 produce a 1056 bp amplicon [GenBank accession no. AF169244.2; sense (bases 676-695) 5'TCCGACCCACTTCGGAAACG-3'; and antisense (bases 17121731) 5'-TCCTCAAAGGCGGAGTCCAG-3']. The $18 \mathrm{~S}$ primers mixed with competimers (1.0: 9.0 ratio) produced a 488 bp amplicon. The $18 \mathrm{~S}$ amplicon served as an internal RNA loading control and the presence of competimers attenuated the $18 \mathrm{~S}$ signal. RT reactions were carried out at $42^{\circ} \mathrm{C}$ for 45 minutes followed by denaturation at $95^{\circ} \mathrm{C}$ for $60 \mathrm{~s}$ with a final concentration of $0.5 \mu \mathrm{M}$ primers, $0.25 \mu \mathrm{g}$ of total MDCK cell RNA and $1.5 \mathrm{mM}$ final concentration of $\mathrm{MgCl}_{2}$. PCR amplification (32 cycles) of the resulting cDNA was then performed using the following cycling conditions; $94^{\circ} \mathrm{C}$ for 30 $\mathrm{s}, 50^{\circ} \mathrm{C}$ for $60 \mathrm{~s}$, then $72^{\circ} \mathrm{C}$ for $60 \mathrm{~s}$, on an $\mathrm{MJ}$ Research Thermocycler. The RT-PCR products were then electrophoresed out on a $1 \%$ PCR grade agarose gel containing ethidium bromide and imaged using the BioRad VersaDoc 3000.

\section{Real-Time RT-PCR}

To quantitate changes in gene expression an ABI 7500 Real-time PCR machine was used to survey the expression of MMP-9 or TIMP1. All RNA samples (250 ng) were reversed transcribed to cDNA using MMLV reverse transcriptase with gene-specific primers. Canis familiaris matrix metalloproteinase9 real time primers and probe were designed to span the putative exon 7-8 boundary [GenBank accession no. AF169244.2; sense (1147-1171) 5'- CACTTCGAACTTTGACAGAGACAAG -3'; and antisense (1205-1222) 5'- GCGGCCACAAGGAACAG -3' and MGB probe (1196-1213) 5'- CCCGGACCAAGGATAC -3' ]. Canis familiaris tissue inhibitor of metalloproteinases (TIMP1) real time primer and probe set were designed to span the exon 5-6 boundary [GenBank accession no. AF079767.1; sense (459-480) 5'- GGCTTCACCAAGACCTATGCT-3'; and antisense (539-559) 5'- GTCCACAAGCAGTGAGTGTCA -3' and MDB reporter (487-506) 5'- AACACTGTGCACCCCTCAC -3']. The reaction was incubated for 30 minutes at $42^{\circ} \mathrm{C}$ in a thermocycler. The cDNA samples were then incubated at $95^{\circ} \mathrm{C}$ for $10 \mathrm{~min}$ in the thermocycler to inactivate the reverse transcriptase and activate AmpliTaq DNA polymerase. Additionally, the RT-PCR mix contained TaqMan universal PCR master mix and AmpliTaq DNA polymerase, AmpErase UNG, dNTPs with dUTP, the mixture of gene-specific primers and TaqMan probes for the specific gene products, and RNase-free water. Amplification plots were examined with the accompanying Sequence Detection Software (Applied Biosystems) to determine the threshold cycle $\left(\mathrm{C}_{\mathrm{T}}\right)$. In all reactions endogenous control (18S) was amplified and the $\mathrm{C}_{\mathrm{T}}$ was determined.

\section{Transepithelial Flux Assay}

Confluent MDCK cultures on Transwell inserts were treated in both apical and basolateral chambers with cytokines in the presence and absence of MMP inhibitor. The cells were 
Fig. 2. TNF $\alpha$ and IFN $\gamma$ exposure positively regulate MMP secretion in MDCK cells. Conditioned media was collected from confluent MDCK cultures, the resultant media was used for gelatin zymography to examine MMP activity. The cytokines TNF $\alpha$ and IFN $\gamma$ markedly enhance MMP activity collected from MDCK cultures (Panel A). Media collected from confluent MDCK cell cultures exposed TNF $\alpha / \mathrm{IFN} \gamma$ in the presence of increasing dose of MMP substrate inhibitor (GM6001) were subjected to gelatin zymography (Panel B). In-gel MMP activity was not influenced however the MMP band shifts upward with increasing dose of GM6001 suggesting an inhibition in the MMP maturation process. MMP activity was determined using a fluorescently labelled substrate (Mca-P-L-G-L-Dpa-A$\mathrm{R}-\mathrm{NH}_{2}$ ), from conditioned media (Panel C). Fluorescence accumulation was elevated in media collected from cells exposed to TNF $\alpha$ and IFN $\gamma$. The mean is reported, error bars represent the SE from five independent experiments. A repeated measures analysis was performed on the data to determine if the rate of MMP substrate hydrolysis differed significantly between the control and TNF $\alpha /$ IFN $\gamma$ treatment groups. For each the covariance matrix for the MMP activity at the 12 different time points was modeled using a Toeplitz structure in which the covariance of any two MMP activity measurements for a given sample depends on the time that has elapsed between those two measurements. The rate of reaction for the $\mathrm{TNF} \alpha / \mathrm{IFN} \gamma$ treatment group was significantly higher than that for the control group $(* * * p<.0001)$. The intercepts for the control and TNF $\alpha /$ IFN $\gamma$ treatment groups did not differ significantly $(\mathrm{p}=0.7842)$.

then allowed to incubate at $37^{\circ} \mathrm{C}$ for 24 hours. After the 24 hours, the cells were washed twice with clear DMEM media, and allowed to incubate for another 2 hours in treated clear DMEM media including a fluorescein probe $(10 \mu \mathrm{M} ; 0.3 \mathrm{kDa})$ in the apical chamber. To preserve the hydrostatic pressure equilibrium, $0.5 \mathrm{~mL}$ of media was added to the apical surface of the cells and $1.5 \mathrm{~mL}$ of media was added to the basolateral chamber. Each hour a $90 \mu \mathrm{L}$ aliquot was taken from the basolateral chamber of the plates, a matching aliquot of $30 \mu \mathrm{L}$ was taken from the apical chamber. The samples were diluted 4.5:100 in 1M TRIS pH 8.0 and the fluorescence measured against a standard curve generated on a Hitachi F-2000 fluorescent spectrophotometer.

\section{Statistics}

Multiple comparisons were made using one-way analysis of variance (ANOVA) followed by either the Bonferroni when comparing multiple samples to control or Tukey HSD post-hoc test. A p value $<0.05$ was considered significant.

MMP-9 Regulation in MDCK Cells
A.

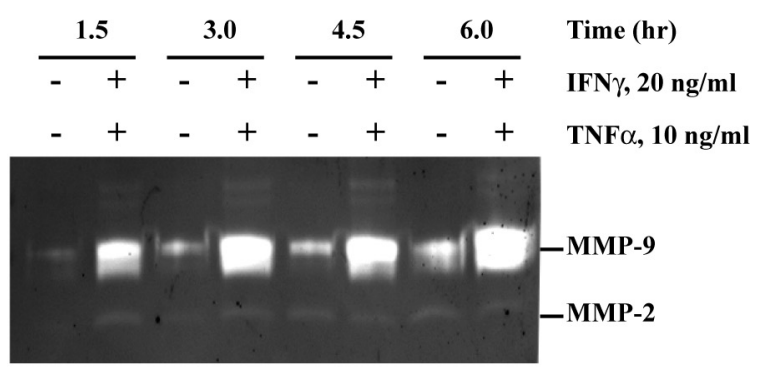

B.

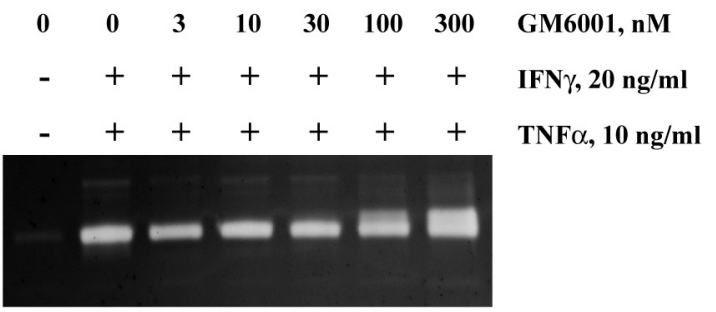

C.

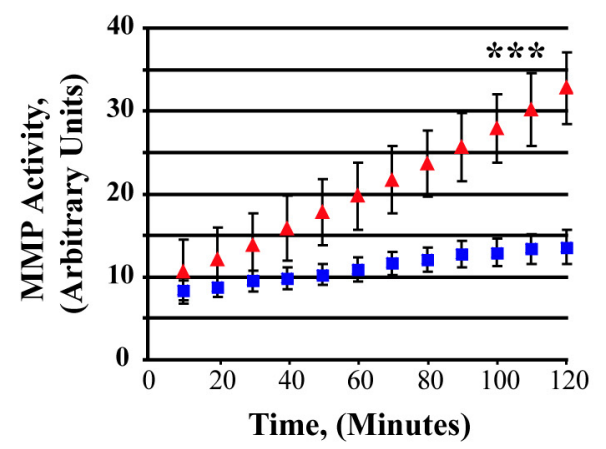

\section{Results}

\section{Paracellular Permeability}

We hypothesized that elevated MMP-9 expression and activity may contribute to increased paracellular flux following exposure to inflammatory cytokines. MDCK cells cultured on Transwell plates to confluency were placed into one of the following groups; either control, $\mathrm{TNF} \alpha / \mathrm{IFN} \gamma(10 / 20 \mathrm{ng} / \mathrm{ml})$, or TNF $\alpha / \mathrm{IFN} \gamma(10 / 20 \mathrm{ng} / \mathrm{ml})$ with GM6001 (10 or $100 \mathrm{nM})$, the MMP substrate inhibitor. We have previously demonstrated that the combination of TNF $\alpha / \mathrm{IFN} \gamma$ disrupts MDCK cell barrier function [25]. The combination of TNF $\alpha / \operatorname{IFN} \gamma(10 / 20 \mathrm{ng} /$ $\mathrm{ml}$ ) caused a decrease in MDCK cell barrier function as indicated by an increase in the diffusive flux rate [27]. Barrier function was recovered by GM6001 in a dose dependent manner (Figure 1). These results implicate 
Fig. 3. Effect of MAP kinase inhibitors on MMP activity released following TNF $\alpha$ and IFN $\gamma$ exposure. Conditioned media was collected from confluent MDCK cultures incubated for twenty-four hours in the indicated conditions. The media analyzed by gelatin zymography (Panel A). The ERK1/2 and p38 inhibitors attenuate the zymographic activity observed compared to the TNF $\alpha$ and IFN $\gamma$ alone. Panel B is a representative MMP-9 Western blot from conditioned media indicating that decreased activity in Panel A is correlated to lower MMP-9 protein expression.

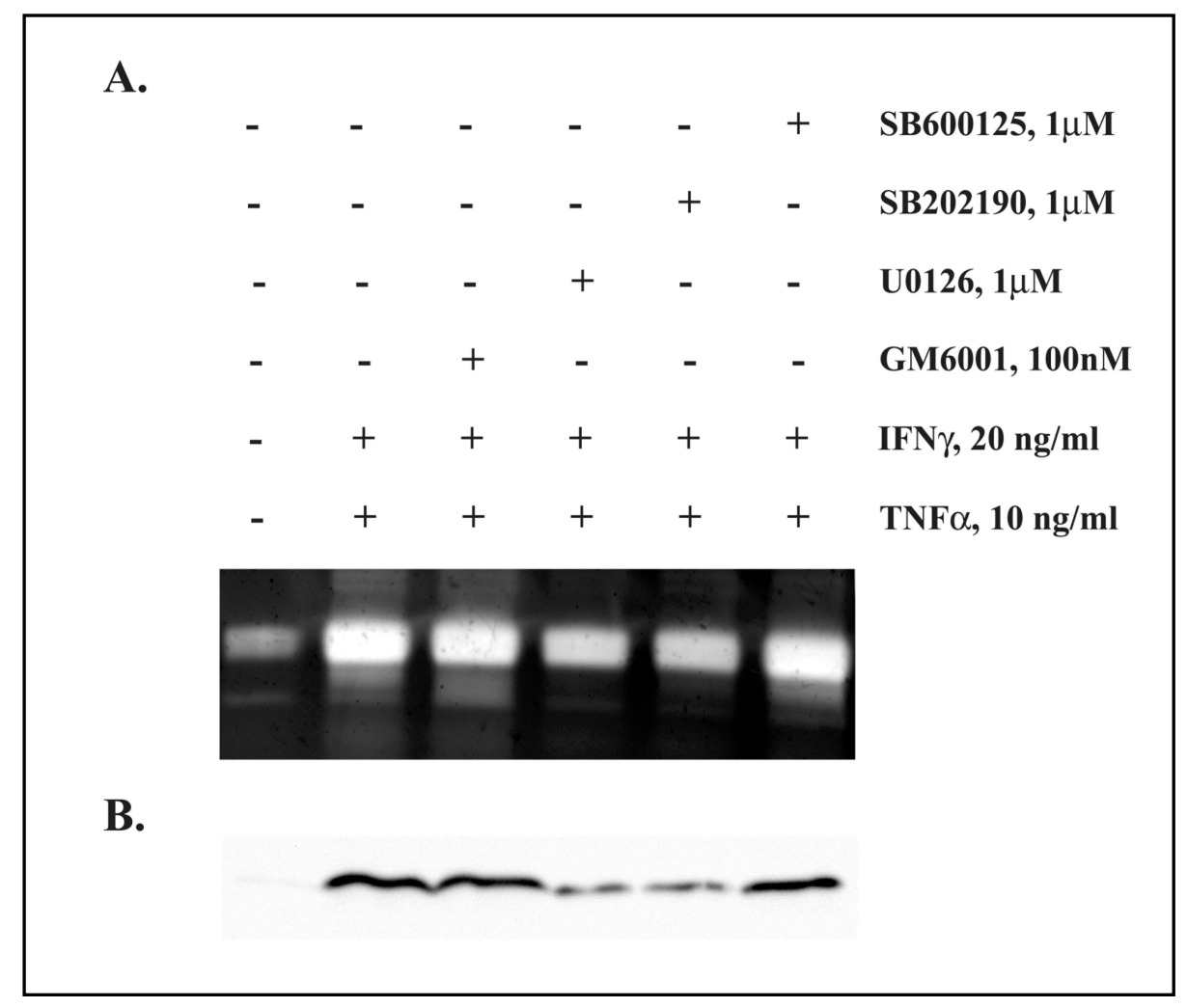

MMP activity in the observed loss of barrier function.

\section{Protease activity enhanced in TNF $\alpha / I F N \gamma$-treated} MDCK cells

To ascertain whether MMPs were being secreted we assessed MMP activity after treating cells with TNF $\alpha$ and IFN $\gamma$ using gelatin zymography. MDCK cells were treated for 18 hours in the absence or presence of TNF $\alpha /$ IFN $\gamma(10 / 20 \mathrm{ng} / \mathrm{ml})$ and then switched into serum-free conditions. Media was then collected at 90 minute intervals for 6 hours. Conditioned media $(20 \mu \mathrm{g})$ was separated electrophoretically, followed by in-gel protein renaturation, gelatin digestion, and staining with Coomassie Blue. In this assay, clear bands in the gel represent enzymatic activity. The active MMPs can be identified on the basis of molecular weight and substrate specificity. Using these criterion, we observed that MMP-9 secretion appears to be markedly augmented following TNF $\alpha /$ IFN $\gamma$ exposure (Figure 2A). Additionally, based on molecular weight it appears that MMP-2 levels are not elevated by cytokine stimulation but are constitutively secreted at low levels. This suggests that the effects of the proinflammatory stimuli are specific to MMP-9.

We examined the effect of GM6001 on MMP-9 processing in vivo. MDCK cells were treated with $\mathrm{TNF} \alpha / \mathrm{IFN} \gamma(10 / 20 \mathrm{ng} / \mathrm{ml})$ for 24 hours in the absence or presence of increasing doses of GM6001 (Figure 2B). The conditioned media was again used in a zymography assay. Based on observed gelatin degrading activity GM6001 did not attenuate TNF $\alpha /$ IFN $\gamma$-induced MMP-9 activity. However, at the highest doses of GM6001 (100 and $300 \mathrm{nM}$ ) we observed an upward shift in MMP-9 mobility, this suggests that although the MDCK cells were actively synthesizing MMP-9 there was incomplete posttranslational processing.

To examine TNF $\alpha /$ IFN $\gamma$-induced proteolytic activity in a quantitative fashion, a fluorescent based MMP activity assay was employed. Conditioned media from 24 hour control and TNF $\alpha /$ IFN $\gamma$-treated MDCK cells was incubated with the fluorogenic substrate (7Methoxycoumarin-4-yl)acetyl-Pro-Leu-Gly-Leu-N-3(2, 4-Dinitrophenyl)-L-2, 3-diaminopropionyl-Ala-Arg- $\mathrm{NH}_{2}$ ) [26]. Regression analysis indicates a significant elevation in the rate of MMP substrate hydrolysis in the media collected from the TNF $\alpha / \mathrm{IFN} \gamma$ treatment group. Collectively, these data demonstrate that MDCK cells exposed to TNF $\alpha /$ IFN $\gamma$ release enzymatically active MMP-9. 
Fig. 4. Effect of Inflammatory Cytokine over Time on MMP-9 mRNA Expression. The effect of MMP-9 mRNA expression determined over time in the presence of TNF $\alpha /$ IFN $\gamma$ (Panel A). MMP-9 mRNA levels were measured without TNF $\alpha / \operatorname{IFN} \gamma$ as the control at 0 hours. Following the addition of TNFa/ IFN $\gamma(10 / 20 \mathrm{ng} / \mathrm{ml})$ MMP-9 mRNA levels were measured at the indicated time intervals. The mean fold increase is reported, error bars represent the $\mathrm{SE}$, four independent experiments were assayed in duplicate. A one-way analysis of variance (ANOVA) was performed, multiple comparisons between control and treatments were determined with the Bonferroni post test. **Indicates statistical difference $(\mathrm{P}<0.001)$ to control. The expression of TIMP1 (Panel B) was examined at 24 hours following addition of TNF $\alpha /$ IFN $\gamma$ by real-time RT-PCR. The $\triangle \triangle \mathrm{CT}$ is reported, error bars represent the $\mathrm{SE}$, four independent experiments were assayed in duplicate.

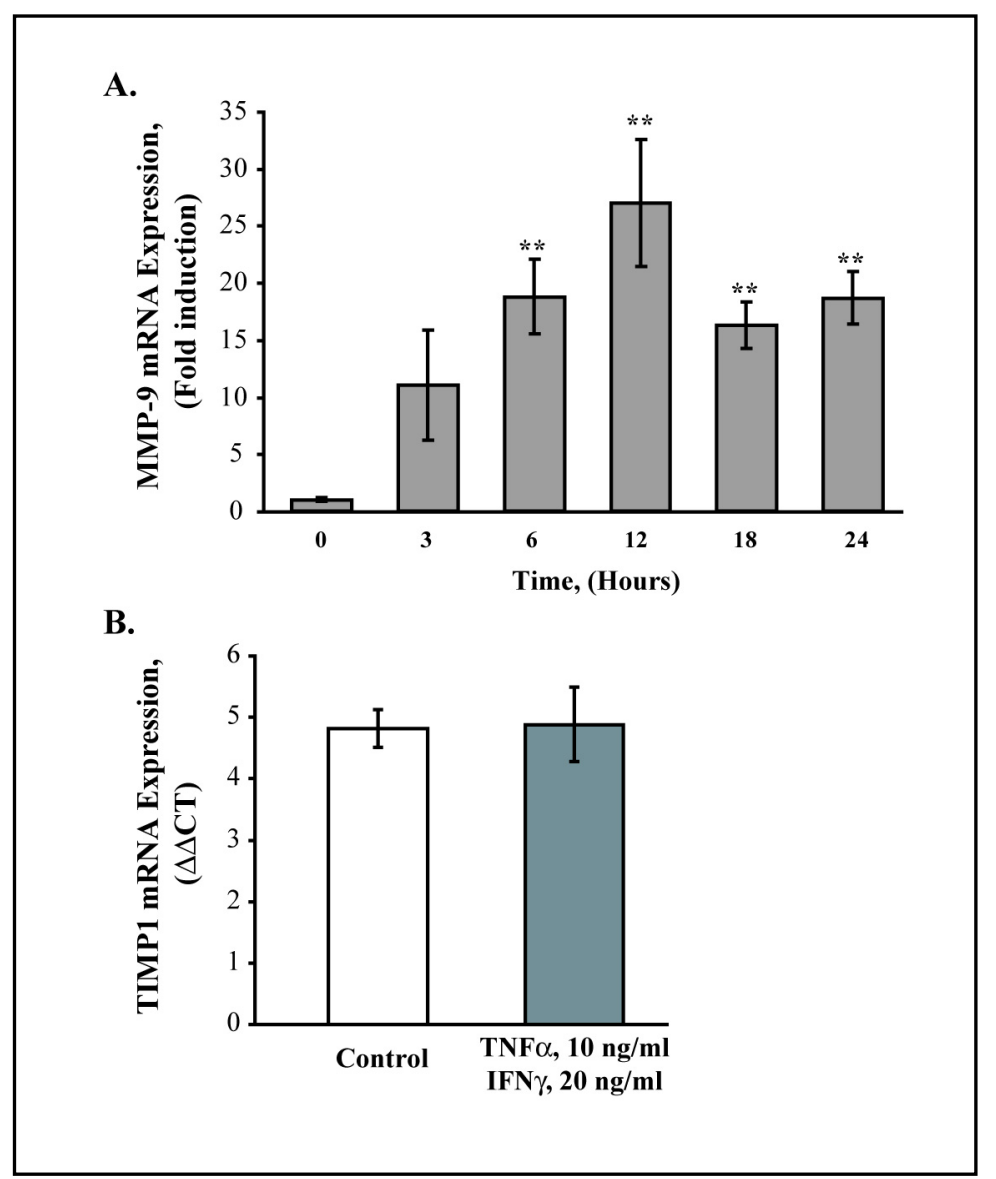

MAP kinase inhibitors influence MMP release from $T N F \alpha / I F N \gamma$-treated $M D C K$ cells

Previous studies suggest that the MAPK pathway is one element regulating the activity of MMP-9. Experiments were designed to assess the effects of inhibiting this pathway after treatment with $\mathrm{TNF} \alpha$ and IFN $\gamma$. MDCK cells were treated with TNF $\alpha / \operatorname{IFN} \gamma(10 /$ $20 \mathrm{ng} / \mathrm{ml}$ ) in the presence of a panel of MAP kinase inhibitors and then conditioned MDCK media was analyzed by gelatin zymography (Figure $3 \mathrm{~A}$ ). These results demonstrate a marked increase in MMP-9 activity and protein levels following TNF $\alpha / \mathrm{IFN} \gamma$ exposure. Additionally, U0126 and SB202190, the ERK 1/2 and p38 MAP kinase inhibitors respectively, attenuate cytokineinduced MMP-9 secretion. By contrast, inhibitors of the JNK pathway did not seem to affect the activity of TNF $\alpha /$ IFN $\gamma$-induced MMP-9 as assayed by gelatin zymography. Western blots indicated that the amount of secreted MMP-9 reflected a similar pattern (Figure 3B). These complementary approaches indicate that increased MMP9 activity corresponds to increased protein production.

MMP-9 Regulation in MDCK Cells

\section{Matrix Metalloproteinase-9 mRNA Expression}

Following examination of protein levels and enzyme activity experiments were conducted to determine if the increased secretion of MMP-9 reflected increased rates of transcription. MMP-9 mRNA expression was assessed using both gel-based and real-time RT-PCR methods. MDCK cell exposure to TNF $\alpha / \operatorname{IFN} \gamma(10 / 20 \mathrm{ng} / \mathrm{ml})$ resulted in a significant elevation of MMP-9 expression that was observed as early as 6 hours post inflammatory cytokine exposure (Figure 4A). The increase in MMP-9 expression is profound and sustained. The expression of TIMP1 was measured to determine if the endogenous inhibitor of MMP-9 responded to the inflammatory regime. There was no change in TIMP1 mRNA expression in MDCK cells exposed to TNF $\alpha / \operatorname{IFN} \gamma(10 / 20 \mathrm{ng} / \mathrm{ml})$ for twenty-four hours (Figure 4B). Next, the effect of either TNF $\alpha$ or INF $\gamma$ was examined on MMP-9 expression (Figure 5). TNF alone potently increased MMP-9 mRNA expression to levels greater than TNF $\alpha / \mathrm{IFN} \gamma$ in combination. In contrast, IFN $\gamma$ alone did not effect MMP9 expression in this system. 
Fig. 5. Effect of Inflammatory Cytokine Concentration on MMP-9 mRNA Expression. Fold increase of MMP-9 mRNA was measured in confluent MDCK cell cultures twenty-four hours following exposure to increasing doses of TNF $\alpha$ and/or IFN $\gamma$. TNF $\alpha$ potently elevates MMP-9 mRNA expression whereas IFN $\gamma$ failed to induce expression. Error bars represent the mean fold increase \pm SE of four independent experiments. ANOVA was performed, multiple comparisons between all treatments were determined with the TukeyHSD post test. **Indicates statistically difference $(\mathrm{p}<0.001)$ to the control group, $* * *$ indicates statistically difference $(\mathrm{p}<0.001)$ to the $\mathrm{TNF} \alpha / \mathrm{IFN} \gamma$ group.

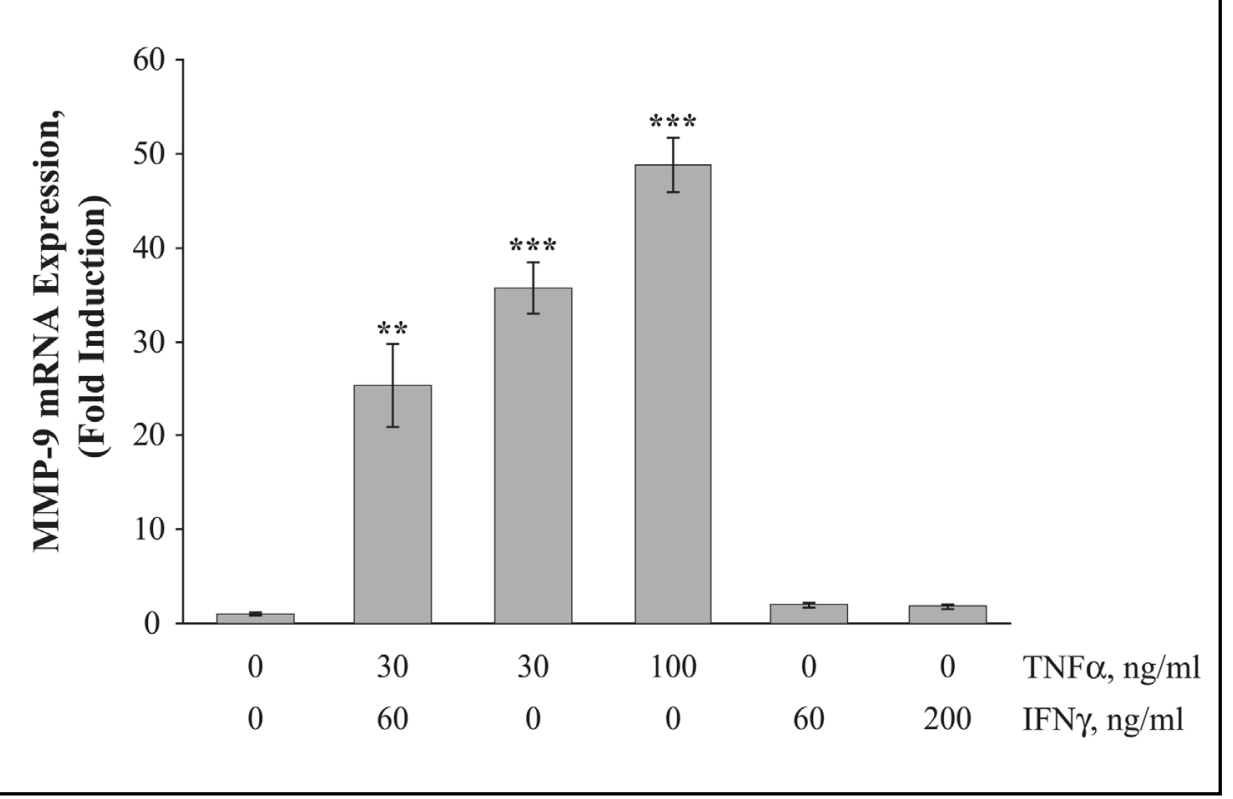

\begin{tabular}{lcccc}
\hline & \multicolumn{5}{c}{ MMP Enzvmatic Activitv (AU) } \\
\hline TNF $\alpha(\mathrm{ng} / \mathrm{ml})$ & 0 & 3 & 10 & 30 \\
Apical Chamber & $1.03 \pm 0.06$ & $3.64 \pm 0.48^{*}$ & $6.02 \pm 0.40^{*}$ & $9.49 \pm 0.43^{*}$ \\
Basal Chamber & $0.51 \pm 0.03$ & $1.02 \pm 0.18$ & $1.16 \pm 0.15$ & $2.22 \pm 0.20^{*}$ \\
\hline
\end{tabular}

Table 1. Analysis of MMP-9 secretion pattern in MDCK cells. Confluent MDCK cell culture grown on Transwell filters were exposed to the indicated dose of TNF $\alpha$ for 12 hours. Media was switched to a low serum media and collected 24 hours later from both the apical and basal chambers. MMP activity was measured from the conditioned media samples and normalized based on volume of the chambers. Conditioned media was incubated with the fluorogenic MMP substrate for 60 minutes at $37^{\circ} \mathrm{C}$ and the mean fluorescence liberated $\pm \mathrm{SE}$ is reported from four independent experiments. ANOVA was performed followed by a Bonferroni post test with all comparisons against the $0 \mathrm{ng} / \mathrm{ml}$ TNF $\alpha$ group, ${ }^{*} \mathrm{P}<0.001$.

RT-PCR experiments were used to assess MMP-9 and $18 \mathrm{~S}$ gene expression. Gene specific primers were designed to produce a $1056 \mathrm{bp}$ amplicon for MMP-9 and a $488 \mathrm{bp}$ amplicon for 18S. Figure 6A demonstrates that MMP-9 mRNA expression is markedly increased following exposure to TNF $\alpha /$ IFN $\gamma$ compared to control. When U0126 $(1 \mu \mathrm{M})$, a MAPK inhibitor, was administered 15 minutes prior to TNF $\alpha / \mathrm{IFN} \gamma$ challenge the upregulation of MMP-9 expression was severely attenuated. To examine the kinetics of the ERK induced upregulation of MMP-9 a time course of U0126 co-treatment was performed by adding U0126 at 2, 4, 6 or 8 hours following $\mathrm{TNF} \alpha / \mathrm{IFN} \gamma$ treatment. In these assays U0126 was ineffective at preventing elevated MMP-9 expression when administered after the cytokine stimuli (data not shown). Analysis of MMP-9 regulation in the presence of MAP kinase or MMP substrate inhibitor was conducted (Figure 6B). The presence of the MAPK inhibitor U0126 did not alter the expression of MMP-9 unless the cells were treated with pro-inflammatory cytokines suggesting that induction of MMP-9 is unique to an inflammatory state. Co- or post administration of U0126 was ineffective at inhibiting MMP-9 upregulation. Similarly, inhibition using SB202190 $(1 \mu \mathrm{M})$, the p38 inhibitor, significantly attenuated MMP-9 mRNA expression in response to TNF $\alpha / \mathrm{IFN} \gamma$ exposure. In contrast, pre-treatment with GM6001, the MMP substrate inhibitor, did not influence the TNF $\alpha /$ IFN $\gamma$ increase in MMP-9 expression.

Leone/Chun/Koehler/Caranto/King 
Fig. 6. Effect of MAP kinase inhibition on MMP9 mRNA Expression. Gel based semi-quantitative RT-PCR was used to examine MMP-9 expression from MDCK cells treated for twenty-four hours in the indicated conditions (Panel A). MMP-9 expression is potently elevated following exposure to cytokine, the ERK1/2 inhibitor markedly attenuated MMP-9 expression. The effect of MAP kinase and substrate inhibitors in the presence of TNF $\alpha$ and IFN $\gamma$ on the expression of MMP-9 mRNA levels was investigated using real time RT-PCR. MDCK cells were placed into one of eight treatment groups for 24 hours; control, U0126 (1 $1 \mu \mathrm{M}), \mathrm{TNF} \alpha /$ IFN $\gamma$ alone $(10 / 20 \mathrm{ng} / \mathrm{ml})$, or proinflammatory cytokines with substrate inhibitor GM6001 (100nM), SB202190 $(1 \mu \mathrm{M}), \mathrm{U} 0126(1 \mu \mathrm{M})$ added 15 minutes prior, simultaneously, or 120 minutes after proinflammatory cytokines. The mean fold increase is reported, error bars represent $\mathrm{SE}$, four independent experiments were assayed in duplicate. **Indicates statistical difference $(\mathrm{P}<0.001$ to control, $* * *$ indicates statistical difference $(\mathrm{P}<$ $0.001)$ to TNFá/IFNã alone).
A.
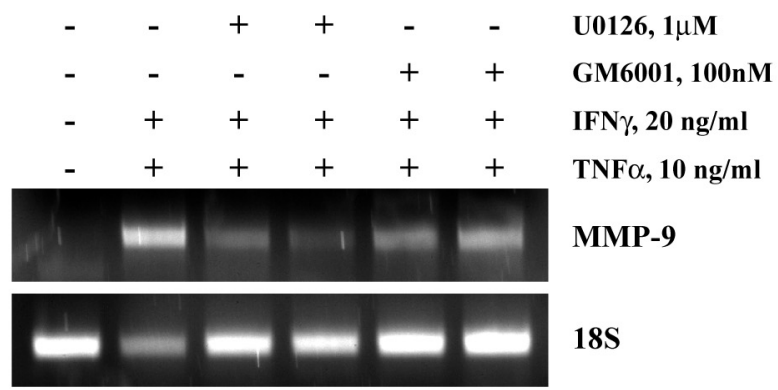

$18 S$

B.

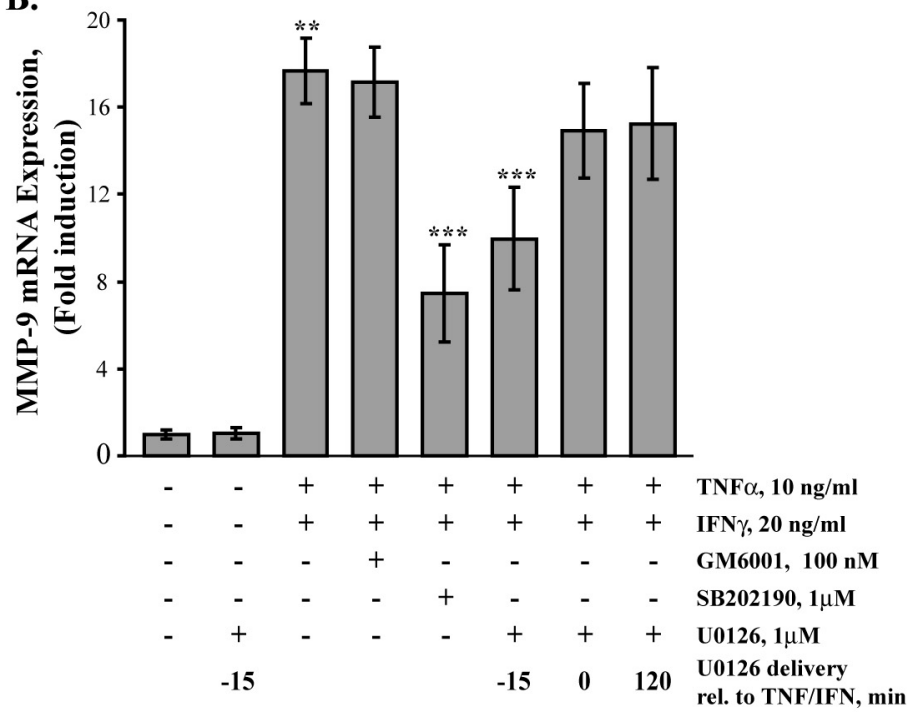

Table 2. Endogenous MMP activity in MDCK cells. Confluent MDCK cell culture grown on Transwell filters were exposed to the indicated dose of TNF $\alpha$ for 12 hours. Media was switched to a low serum media and collected 24 hours later from the apical chamber. Conditioned media was

\begin{tabular}{lcr}
\hline & \multicolumn{2}{c}{ TNF $\alpha(10 / \mathrm{ng} / \mathrm{ml})$} \\
& \multicolumn{1}{c}{-} & \multicolumn{1}{c}{+} \\
\hline MMP Activity ( AU) without APMA & $2.94 \pm 0.15$ & $4.04 \pm 0.29^{*}$ \\
MMP Activity (AU) with APMA & $3.24 \pm 0.19$ & $13.98 \pm 0.69^{*}$ \\
\% Endogenously Active & $90.6 \pm 2.6 \%$ & $28.9 \pm 2.6 \%$ \\
\hline
\end{tabular}
incubated in MMP assay buffer in the presence and absence of APMA. Conditioned media was incubated with the fluorogenic MMP substrate for 60 minutes at $37^{\circ} \mathrm{C}$ and the mean fluorescence liberated (arbitrary units) $\pm \mathrm{SE}$ is reported from four independent experiment. Pairwise comparisons for significance was determined using an independent sample t-test, an asterisk indicates a $\mathrm{P}$ value $<0.001$.

\section{Matrix Metalloproteinase Secretion}

In order to determine the physiological location of MMP activity we conducted a study using confluent MDCK cultures grown on Transwell inserts. MMP activity was determined from control or TNF $\alpha$ stimulated cells using conditioned media collected from both apical and basal chambers. The conditioned media was activated by APMA treatment to assess the total amount of MMP activity. MMP activity is significantly increased by TNF $\alpha$ in a dose dependent manner (Table 1). We observed more than a nine-fold elevation in activity in the apical chamber in response to TNF $\alpha(30 \mathrm{ng} / \mathrm{ml})$. However, all measured doses of TNF $\alpha$ resulted in a significant elevation in MMP 
Fig. 7. Effect of recMMP-9 on fluorescein flux in MDCK cells. Fluorescein flux rate was determined after treating confluent MDCK cell cultures grown on Transwell supports for 60 minutes at $37^{\circ} \mathrm{C}$ with the indicated doses of recMMP-9 and GM6001. Fluorescein $(30 \mu \mathrm{M})$ was added to the apical chamber and recovery was measured from the basal chamber after 120 minutes of incubation. Mean fluorescence $\pm \mathrm{SE}$ is reported of six independent experiments. ANOVA was performed followed by a Tukey-HSD post test for significance. $\quad * *$ Indicates statistical significance $(\mathrm{P}<0.001)$ to control, ***indicates a significant $(\mathrm{P}<0.001)$ to recMMP9 alone.

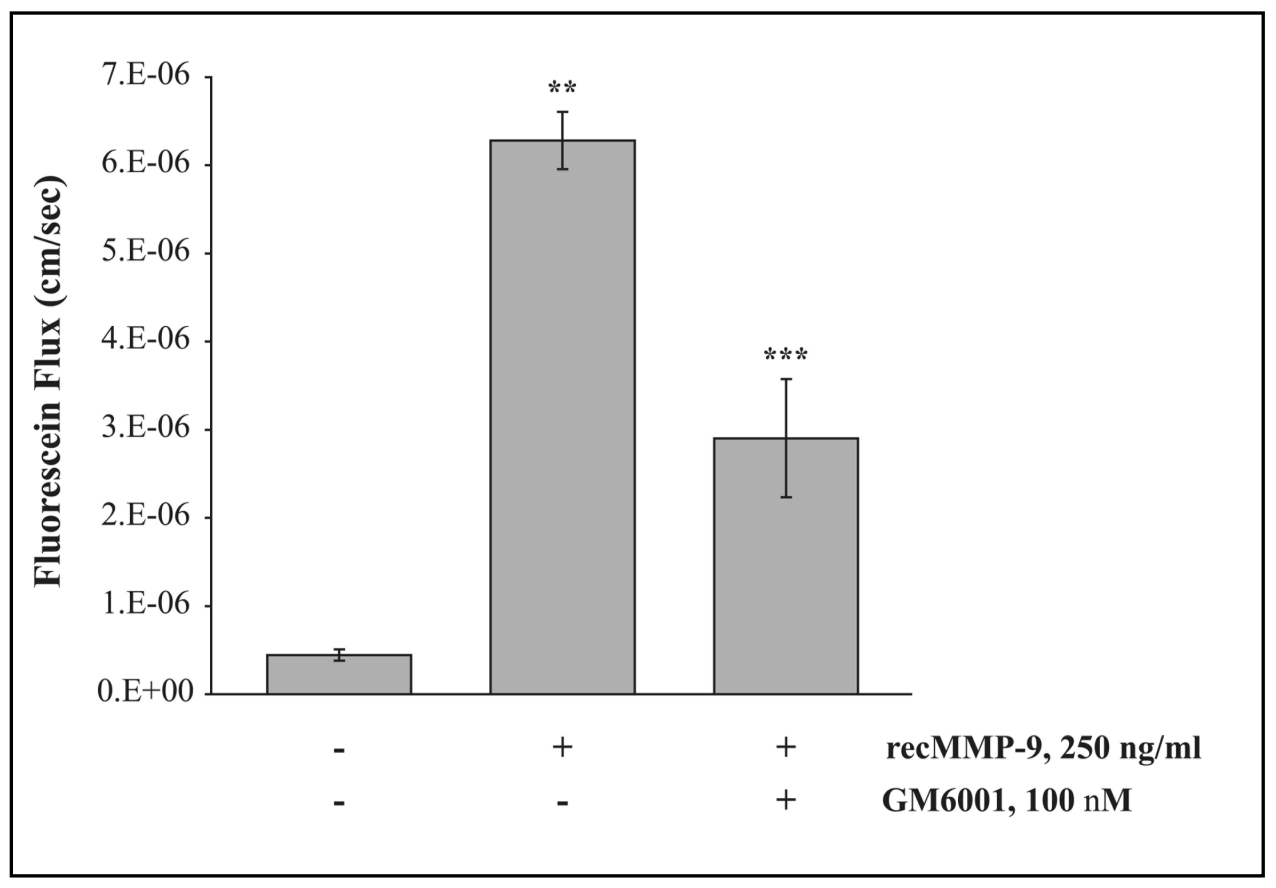

activity in the apical chamber. In comparison, MMP activity in the basal chamber was markedly lower and only the highest dose of TNF $\alpha(30 \mathrm{ng} / \mathrm{ml})$ resulted in a significant elevation. These results demonstrate that MDCK cells secrete a majority of the MMP-9 into the apical chamber.

In an additional study, we determined the fraction of MMP activity that was endogenously active in the conditioned media (Table 2). We report a statistically significant elevation in endogenously active MMP in TNF $\alpha$-treated MDCK cells. Interestingly, in the control media fraction the majority of enzyme secreted is activated. Since MMP secretion is markedly elevated following exposure to TNF $\alpha(10 \mathrm{ng} / \mathrm{ml})$ this results in a larger fraction of endogenously inactive MMP in the conditioned media.

\section{Recombinant Matrix Metalloproteinase-9} Elevates Paracellular Permeability

We investigated whether direct addition of mouse recombinant $\mathrm{MMP}-9$ (recMMP-9) to the apical compartment would elevate paracellular flux. The rationale was two-fold, the propensity for MMP-9 to be secreted into the apical compartment and the tight junction complex is recognized as most apical junctional structure. Based on studies examining endogenously active MMP9 secreted by MDCK cells and using a standard curve of recMMP-9 we determined that $250 \mathrm{ng} / \mathrm{ml}$ of recMMP-9 would be an appropriate dose. We find a marked elevation in fluorescein flux rate that increases over time when a physiologically relevant dose of MMP-9 was applied to the apical surface of MDCK cultures (Figure 7). The increase in diffusive flux rate was significantly attenuated in samples concurrently treated with recMMP-9 and GM6001.

\section{Discussion}

The integrity of epithelium is essential for normal renal function, and a common hallmark of kidney dysfunction is impaired cellular junctions [4]. Inflammatory conditions within the renal environment may lead to loss or rearrangement of cellular junctions altering important parameters such as glomerular filtration, ionic balance or accumulation of metabolic toxins. TNF $\alpha$ is a potent activator of inflammatory episodes and has been demonstrated to be a key regulator of renal injury [28]. There has been growing interest in the field but the precise mechanisms leading to junctional disruption remain elusive. MMPs are major players in extracellular membrane remodeling particularly during inflammation responses and wound repair [20]. We employed the established MDCK renal epithelial cell model to examine the effects of proinflammatory cytokine exposure on gelatinase activity and cell barrier function. 
In this study we found that MDCK cells exposed to TNF $\alpha$ and IFN $\gamma$ potently increased gelatinase activity. Based on the apparent molecular weight of the observed from the zymography and the gelatin substrate we speculated that MMP-9 activity was enhanced in MDCK cells following exposure to TNF $\alpha$ and IFN $\gamma$. Previous work suggests that MMP-9 is inducible by both growth factors and proinflammatory cytokines in other epithelial model systems. For example, MMP-9 is upregulated in response to TNF $\alpha$ and IL-1 $\beta$ in Caco- 2 cells [29], EGF in renal principle cells [30], and by both phorbol esters and at the margin of proliferating cell layers in glomerular epithelial cells [12]. The study by McMillan et al. suggested that aberrant upregulation of MMP-9 in glomerular epithelium is associated with progression of membranous nephropathy indicating a role for this proteinase in disease pathology [12]. Collectively, these studies and others provide a framework to explore the regulation of MMP-9 in renal epithelium.

We employed the use of a synthetic active site MMP inhibitor, GM6001, in this study [31,32]. The presence of this inhibitor (GM6001) did not prevent expression or secretion of MMP-9, however its maturation and activity were inhibited. Several convergent lines of evidence support these findings. For instance, MMP-9 was detected as a secreted protein in the culture supernatant irrespective of the concentration of GM6001 added to the media. Secondly, GM6001 appeared to inhibit the maturation of MMP-9 by preventing cleavage of the propeptide to the fully active form of the enzyme (Figure 2B). This resulted in decreased mobility through a nondenaturing SDS-PAGE gel. It is important to note that while in vivo the activity of MMP-9 would be inhibited by the pro-peptide; the zymographic process results in partial denaturation permitting the active site to become hydrated resulting in MMP-9 activity and a band with less mobility than the fully processed form of the enzyme. Being that MMP-9 is secreted as an inactive zymogen it requires additional extracellular proteolytic processing to be activated. Proteolytic processing of MMP-9 is known to involve a multiple protein complex including MMP-2, TIMP-2 and MT-MMP1 [33-36]. Additionally, it has been demonstrated that plasmin can activate MMP-3 which then can proteolytically process MMP-9 [37, 38]. Interestingly, we find that although the endogenously active quantity of MMP-9 increases following exposure to proinflammatory cytokine exposure, there remains a large reservoir of secreted inactive MMP-9 (Table 2). The lack of concomitant elevation of MMP-2 in this study suggests that this may a rate-limiting step in the maturation

MMP-9 Regulation in MDCK Cells of secreted MMP-9.

In the present study, we verified that TNF $\alpha$ exposure regulates MMP-9 at the transcriptional level resulting in increased MMP-9 mRNA expression which is reflected in increased protein accumulation and increased enzymatic activity. Both MMP-9 mRNA and protein accumulated with increasing time of exposure. In this system, we observed that MMP-2 enzymatic activity is unaffected by $\mathrm{TNF} \alpha$ treatment suggesting that $\mathrm{TNF} \alpha$ selectively increases the activity of MMP-9. An interesting study demonstrated that MDCK cells exposed to influenza A elevated MMP-2 levels but not MMP-9 [39]. It is not surprising to find that MMP regulation in MDCK cells is based on specific external or internal cues. Additionally, we observed more robust MMP-9 mRNA expression in response to TNF $\alpha$ alone, the presence of IFN $\gamma$ reduced the overall response. This finding is consistent with other studies that have demonstrated that IFN $\gamma$ suppresses MMP-9 expression through a STAT signaling mechanism [40].

Transcription regulation is a primary determinate of MMP-9 levels although an overall increase in transcription may or may not lead to changes in the proteolytic state based on the expression of TIMP-1, the endogenous inhibitor of MMP-9. We measured TIMP-1 expression following exposure to a combination of TNF $\alpha / \mathrm{IFN} \gamma$ and found basal levels of TIMP-1 expression were unaffected. Therefore TIMP-1 expression was not regulated in a coordinated fashion with MMP-9. Thus during an inflammatory insult this will lead to a state with elevated MMP-9 proteolytic activity. In good agreement with our findings, investigators found that TNF $\alpha$ increased MMP9 levels while reducing TIMP-1 expression using a renal proximal kidney cell model [41]. Based on the physiological stimulus and or cell type it is possible to find coordinated TIMP-1 and MMP-9 expression. In contrast to findings in renal systems both MMP-9 and TIMP-1 expression levels increased in response to TNF $\alpha$ in several studies using lung epithelial cell models [42, 43].

MMP-9 transcriptional activation requires binding to upstream AP-1 and NF- $\mathrm{KB}$ sites. The MMP-9 promoter region contains AP-1 sites that are regulated by the MAPK pathway. MMP-9 has also been observed to have a positive feedback effect on its own regulation by catalyzing the release of cytokines (TNF- $\alpha$, IL-1 $\beta$ ) bound to the ECM. Recent studies have shown substantial evidence that there is a direct correlation between the expression of c-jun and MMP-9 expression, though this site is regulated by the dimer combinations of c-jun and c-fos formed with some serving as inhibitors [24, 44]. In 
the present study, we find that inhibition of either ERK1/ 2 or p38 signaling significantly attenuated MMP-9 transcription during exposure to TNF $\alpha$ and IFN $\gamma$. Interestingly, we find that the ERK inhibitor must be present prior to TNF $\alpha / \mathrm{IFN} \gamma$ exposure in order to inhibit MMP-9 transcription suggesting that this is a primary effect of cytokine exposure. A series of recent investigations have determined that elevated glucose levels stimulates MMP-9 expression through the ERK signaling pathway $[45,46]$.

During the inflammatory challenge presented in this study, we observed an increase in the paracellular permeability of the MDCK layer in response to TNF $\alpha$ and IFN $\gamma$. We carefully examined whether necrotic or apoptotic events triggered elevated paracellular flux in a previous study. We found no evidence of a cytotoxic effect using doses of TNF $\alpha$ and IFN $\gamma$ that were employed in this current study. Interestingly, we observed significant reorganization of junctional proteins including; occludin, claudin-1 and claudin-2 [25]. In the present study, an MMP active site inhibitor (GM6001) exerted a protective effect in a dose-dependent manner in the presence of proinflammatory cytokines on barrier function. This implicates MMP-9 activity in the observed attenuation of barrier function. We hypothesize that MMP-9 acts to degrade components of the tight junction found on the apical face of the polarized epithelium including occludin and claudin. Previous work by a number of groups offers support for this hypothesis. For example, recently, MMP2 and MMP-9 were immunolocalized to the apical pole in rabbit collecting ducts [30]. Direct proteolysis of occludin by an MMP-9 mediated process has been observed following tyrosine phosphatase inhibition, during apoptosis and by dendritic cells [47-49]. We find large quantities of MMP-9 are secreted into the apical compartment potentially contributing to the destabilization of the junctional complexes. To test this hypothesis we applied a physiologically-relevant dose of recombinant MMP-9 to the apical chamber of confluent MDCK cultures. This resulted in significant elevation in diffusive flux rate providing support for the MMP-9-mediated junctional disruption mechanism.

In a series of recent studies examining the role of the transcription factor Snail, MDCK cell permeability was elevated by decreasing expression of claudins $-2,-4$ and -7 in response to Snail activity [50]. Additionally, Snail was found to facilitate the epithelial-mesenchyme transition by the induction of MMP-9 activation in MDCK cells through a MAPK pathway [51]. A detailed series of studies suggests extensive cross talk between the apical junction components and MMP-9 activity. Following ischemia, it has been demonstrated that E-cadherin cleavage is mediated by an MMP activator, MT1-MMP $[52,53]$. Abrogation of E-cadherin function via blocking antibodies has recently been shown to induce MMP-9 expression [54]. In a second example of cross talk, claudins have been shown to regulate MT1-MMP expression [31]. We have previously demonstrated that inhibition of ERK1/2 signaling in TNF $\alpha /$ IFN $\gamma$-exposed MDCK monolayers resulted in decreased paracellular flux exerting a protective effect on cell junctions [25]. In conjunction with our current findings that ERK $1 / 2$ inhibition attenuates MMP-9 expression, these data suggest an ERK mediated role for MMP-9 in degradation of apical junction components.

In conclusion, we have demonstrated that a renal epithelial cell model (MDCK cells) produces MMP-9 in response to proinflammatory cytokine exposure. Pharmacological inhibition of the ERK and $\mathrm{p} 38$ pathways attenuated the TNF $\alpha$-induced MMP-9 response. Inhibition of MMP activity had a protective effect on MDCK barrier function in cytokine-stimulated cells. Direct addition of recombinant MMP-9 to the apical chamber significantly elevated paracellular permeability confirming the relationship between MMP-9-mediated junctional disruption and barrier function in MDCK cells. Future studies will focus on identifying MMP-9 substrates at the apical surface of the renal epithelium.

\section{Acknowledgements}

This work was supported in part by National Institutes of Health Grant DK065652 and W.M. Keck Foundation. The authors would like to thank Darcy L. Derickson and Jonathan D. Scudder for their excellent technical contribution and Dr. Diane Saphire for her statistical analyses. A.K. Leone was supported in part by the National Science Foundation (MUE0200148) and C.L. Koehler is a recipient of the Beckman Scholar Fellowship. 


\section{References}

$\rightarrow 1$ Schneeberger EE, Lynch RD: The tight $\nabla_{13}$ junction: a multifunctional complex. Am J Physiol Cell Physiol 2004:286(6):C1213-1228.

-2 Cereijido M, Shoshani L, Contreras RG: Molecular physiology and $>14$ pathophysiology of tight junctions. I. Biogenesis of tight junctions and epithelial polarity. Am J Physiol Gastrointest Liver Physiol 2000;279(3):G477-482.

$\checkmark 3$ Balkovetz DF: Claudins at the gate: determinants of renal epithelial tight junction paracellular permeability. Am J Physiol Renal Physiol 2006;290(3):F572-579.

4 Lee DB, Huang E, Ward HJ: Tight junction biology and kidney dysfunction. Am J Physiol Renal Physiol 16 2006;290(1):F20-34.

-5 Somerville RP, Oblander SA, Apte SS: Matrix metalloproteinases: old dogs with new tricks. Genome Biol 2003;4(6):216. Chang C, Werb Z: The many faces of metalloproteases: cell growth, invasion, angiogenesis and metastasis. Trends Cell Biol 2001;11(11):S37-43.

7 Murphy G, Cawston TE, Reynolds JJ: An inhibitor of collagenase from human amniotic fluid. Purification, characterization and action on metalloproteinases. Biochem J 1981;195(1):167-170.

8 Cambray GJ, Murphy G, Reynolds JJ: The 18 effects of dexamethasone in vitro on the production of collagenase and inhibitor by synovial and cartilage explants from the joints of rabbits with a proliferative arthritis. Rheumatol Int 1981;1(2):6972.

-9 Sellers A, Meikle MC, Reynolds JJ: Collagenase and collagenase inhibitor levels following changes in bone resorption in vitro. Calcif Tissue Int 1980;31(1):35-43.

-10 Nakamura T, Ushiyama C, Suzuki S, Hara M, Shimada N, Ebihara I, Koide H: Urinary excretion of podocytes in 20 patients with diabetic nephropathy. Nephrol Dial Transplant 2000;15(9):1379-1383.

-11 Zaoui P, Cantin JF, Alimardani-Bessette M, Monier F, Halimi S, Morel F, Cordonnier D: Role of metalloproteases and inhibitors in the occurrence and progression of diabetic renal lesions. Diabetes Metab 2000;26 Suppl 4:25-29.

12 McMillan JI, Riordan JW, Couser WG, Pollock AS, Lovett DH: Characterization of a glomerular epithelial cell metalloproteinase as matrix metalloproteinase9 with enhanced expression in a model of membranous nephropathy. J Clin Invest 1996;97(4):1094-1101.
Rankin CA, Suzuki K, Itoh Y, Ziemer DM, Grantham JJ, Calvet JP, Nagase H: Matrix metalloproteinases and TIMPS in cultured C57BL/6J-cpk kidney tubules. Kidney Int 1996;50(3):835-844.

Ebihara I, Nakamura T, Tomino Y, Shimada N, Koide H: Metalloproteinase9 mRNA expression in monocytes from patients with chronic renal failure. Am J Nephrol 1998;18(4):305-310.

Yokoyama H, Wada T, Kobayashi K, Kuno K, Kurihara H, Shindo T, Matsushima K: A disintegrin and metalloproteinase with thrombospondin motifs (ADAMTS)-1 null mutant mice develop renal lesions mimicking obstructive nephropathy. Nephrol Dial Transplant 2002;17 Suppl 9:39-41.

Kuno K, Kanada N, Nakashima E, Fujiki F, Ichimura F, Matsushima K: Molecular cloning of a gene encoding a new type of metalloproteinase-disintegrin family protein with thrombospondin motifs as an inflammation associated gene. J Biol Chem 1997;272(1):556-562.

Medina C, Videla S, Radomski A, Radomski MW, Antolin M, Guarner F, Vilaseca J, Salas A, Malagelada JR: Increased activity and expression of matrix metalloproteinase-9 in a rat model of distal colitis. Am J Physiol Gastrointest Liver Physiol 2003;284(1):G116-122.

Asahi M, Wang X, Mori T, Sumii T, Jung JC, Moskowitz MA, Fini ME, Lo EH: Effects of matrix metalloproteinase-9 gene knock-out on the proteolysis of blood-brain barrier and white matter components after cerebral ischemia. J Neurosci 2001;21(19):7724-7732.

Mori T, Wang X, Aoki T, Lo EH: Downregulation of matrix metalloproteinase-9 and attenuation of edema via inhibition of ERK mitogen activated protein kinase in traumatic brain injury. $\mathrm{J}$ Neurotrauma 2002;19(11):1411-1419.

Alexander JS, Elrod JW: Extracellular matrix, junctional integrity and matrix metalloproteinase interactions in endothelial permeability regulation. $\mathrm{J}$ Anat 2002;200(6):561-574.

Ismair MG, Ries C, Lottspeich F, Zang C, Kolb HJ, Petrides PE: Autocrine regulation of matrix metalloproteinase9 gene expression and secretion by tumor necrosis factor-alpha (TNF-alpha) in NB4 leukemic cells: specific involvement of TNF receptor type 1 . Leukemia 1998;12(7):1136-1143.

-22 Pagenstecher A, Stalder AK, Kincaid CL, Volk B, Campbell IL: Regulation of matrix metalloproteinases and their inhibitor genes in lipopolysaccharideinduced endotoxemia in mice. Am J Pathol 2000;157(1):197-210.
Stamenkovic I: Matrix metalloproteinases in tumor invasion and metastasis. Semin Cancer Biol 2000;10(6):415-433.

24 Campbell SE, Nasir L, Argyle DJ, Bennett D: Molecular cloning and characterization of canine metalloproteinase-9 gene promoter. Gene 2001;273(1):81-87.

-25 Patrick DM, Leone AK, Shellenberger JJ, Dudowicz KA, King JM: Proinflammatory cytokines tumor necrosis factor-alpha and interferongamma modulate epithelial barrier function in Madin-Darby canine kidney cells through mitogen activated protein kinase signaling. BMC Physiol 2006;6(1):2.

Knight CG, Willenbrock F, Murphy G: A novel coumarin-labelled peptide for sensitive continuous assays of the matrix metalloproteinases. FEBS Lett 1992;296(3):263-266.

Chang YS, Munn LL, Hillsley MV, Dull RO, Yuan J, Lakshminarayanan S, Gardner TW, Jain RK, Tarbell JM: Effect of vascular endothelial growth factor on cultured endothelial cell monolayer transport properties. Microvasc Res 2000;59(2):265-277.

Ramesh G, Reeves WB: TNF-alpha mediates chemokine and cytokine expression and renal injury in cisplatin nephrotoxicity. J Clin Invest 2002;110(6):835-842.

29 Gan X, Wong B, Wright SD, Cai TQ: Production of matrix metalloproteinase9 in $\mathrm{CaCO}-2$ cells in response to inflammatory stimuli. J Interferon Cytokine Res 2001;21(2):93-98.

Piedagnel R, Murphy G, Ronco PM, Lelongt B: Matrix metalloproteinase 2 (MMP2) and MMP9 are produced by kidney collecting duct principal cells but are differentially regulated by SV40 large$\mathrm{T}$, arginine vasopressin, and epidermal growth factor. $J$ Biol Chem 1999;274(3):1614-1620.

Miyamori H, Takino T, Kobayashi Y, Tokai H, Itoh Y, Seiki M, Sato H: Claudin promotes activation of pro-matrix metalloproteinase-2 mediated by membrane-type matrix metalloproteinases. J Biol Chem 2001;276(30):28204-28211.

32 Solorzano CC, Ksontini R, Pruitt JH, Hess PJ, Edwards PD, Kaibara A, Abouhamze A, Auffenberg T, Galardy RE, Vauthey JN, Copeland EM, 3rd, Edwards CK, 3rd, Lauwers GY, Clare-Salzler M, MacKay SL, Moldawer LL, Lazarus DD: Involvement of $26-\mathrm{kDa}$ cell-associated TNF-alpha in experimental hepatitis and exacerbation of liver injury with a matrix metalloproteinase inhibitor. J Immunol 1997;158(1):414-419. 
33 Monea S, Lehti K, Keski-Oja J, Mignatti $\mathrm{P}$ : Plasmin activates pro-matrix metalloproteinase-2 with a membranetype 1 matrix metalloproteinasedependent mechanism. J Cell Physiol 2002;192(2):160-170.

Deryugina EI, Ratnikov B, Monosov E, Postnova TI, DiScipio R, Smith JW, Strongin AY: MT1-MMP initiates activation of pro-MMP-2 and integrin alphavbeta 3 promotes maturation of MMP-2 in breast carcinoma cells. Exp Cell Res 2001;263(2):209-223.

Fridman R, Toth M, Pena D, Mobashery $\mathrm{S}$ : Activation of progelatinase B (MMP9) by gelatinase A (MMP-2). Cancer Res 1995;55(12):2548-2555.

Rundhaug JE: Matrix metalloproteinases and angiogenesis. J Cell Mol Med 2005, 9(2):267-285.

$>37$ Ramos-DeSimone N, Hahn-Dantona E, Sipley J, Nagase H, French DL, Quigley JP: Activation of matrix metalloproteinase-9 (MMP-9) via a converging plasmin/stromelysin-1 cascade enhances tumor cell invasion. J Biol Chem 1999;274(19):13066-13076. DeClerck YA, Laug WE: Cooperation between matrix metalloproteinases and the plasminogen activator-plasmin system in tumor progression. Enzyme Protein 1996;49(1-3):72-84.

$>39$ Yeo SJ, Kim SJ, Kim JH, Lee HJ, Kook YH: Influenza A virus infection modulates the expression of type IV collagenase in epithelial cells. Arch Virol 1999;144(7):1361-1370.

Ma Z, Qin H, Benveniste EN: Transcriptional suppression of matrix metalloproteinase-9 gene expression by IFN-gamma and IFN-beta: critical role of STAT-1alpha. J Immunol 2001;167(9):5150-5159.

$\checkmark 41$ Nee LE, McMorrow T, Campbell E, Slattery C, Ryan MP: TNF-alpha and IL1beta-mediated regulation of MMP-9 and TIMP-1 in renal proximal tubular cells. Kidney Int 2004;66(4):1376-1386.
-42 Hozumi A, Nishimura Y, Nishiuma T, Kotani Y, Yokoyama M: Induction of MMP-9 in normal human bronchial epithelial cells by TNF-alpha via NFkappa B-mediated pathway. Am J Physiol Lung Cell Mol Physiol 2001;281(6):L1444-1452.

43 Lacherade JC, Van De Louw A, Planus E, Escudier E, D'Ortho MP, Lafuma C, Harf A, Delclaux C: Evaluation of basement membrane degradation during TNFalpha-induced increase in epithelial permeability. Am J Physiol Lung Cell Mol Physiol 2001;281(1):L134-143.

44 Pacheco MM, Nishimoto IN, Mourao 50 Neto M, Mantovani EB, Brentani MM: Prognostic significance of the combined expression of matrix metalloproteinase9 , urokinase type plasminogen activator and its receptor in breast cancer as measured by Northern blot analysis. Int J Biol Markers 2001;16(1):62-68.

45 Liu S, Liang Y, Huang H, Wang L, Li Y, Li J, Li X, Wang H: ERK-dependent signaling pathway and transcriptional factor Ets-1 regulate matrix metalloproteinase-9 production in transforming growth factor-beta 1 stimulated glomerular podocytes. Cel Physiol Biochem 2005;16(4-6):207216.

$>46$ Bai Y, Wang L, Li Y, Liu S, Li J, Wang H, Huang H: High ambient glucose levels modulates the production of MMP-9 and alpha5(IV) collagen by cultured $>53$ podocytes. Cell Physiol Biochem 2006;17(1-2):57-68.

47 Wachtel M, Frei K, Ehler E, Fontana A, Winterhalter K, Gloor SM: Occludin proteolysis and increased permeability in endothelial cells through tyrosine phosphatase inhibition. J Cell Sci 1999;112 ( Pt 23):4347-4356.
Bojarski C, Weiske J, Schoneberg T, Schroder W, Mankertz J, Schulzke JD, Florian P, Fromm M, Tauber R, Huber O: The specific fates of tight junction proteins in apoptotic epithelial cells. J Cell Sci 2004;117(Pt 10):2097-2107.

Ichiyasu H, McCormack JM, McCarthy KM, Dombkowski D, Preffer FI, Schneeberger EE: Matrix metalloproteinase-9-deficient dendritic cells have impaired migration through tracheal epithelial tight junctions. Am J Respir Cell Mol Biol 2004;30(6):761770 .

Carrozzino F, Soulie P, Huber D, Mensi N, Orci L, Cano A, Feraille E, Montesano $\mathrm{R}$ : Inducible expression of Snail selectively increases paracellular ion permeability and differentially modulates tight junction proteins. Am J Physiol Cell Physiol 2005;289(4):C1002-1014.

$>51$ Jorda M, Olmeda D, Vinyals A, Valero E, Cubillo E, Llorens A, Cano A, Fabra A: Upregulation of MMP-9 in MDCK epithelial cell line in response to expression of the Snail transcription factor. J Cell Sci 2005;118(Pt 15):33713385 .

Covington MD, Bayless KJ, Burghardt RC, Davis GE, Parrish AR: Ischemiainduced cleavage of cadherins in NRK cells: evidence for a role of metalloproteinases. Am J Physiol Renal Physiol 2005;289(2):F280-288.

Covington MD, Burghardt RC, Parrish AR: Ischemia-induced cleavage of cadherins in NRK cells requires MT1MMP (MMP-14). Am J Physiol Renal Physiol 2006;290(1):F43-51.

Fiorino AS, Zvibel I: Disruption of cellcell adhesion in the presence of sodium butyrate activates expression of the 92 $\mathrm{kDa}$ type IV collagenase in MDCK cells. Cell Biol Int 1996;20(7):489-499. 